\title{
現下我が國内地に於ける石炭問題の二, 三に就て
}

——昭和 17 年 6 月 13 日, 第 191 间例會講演 —

石炭統制會生産部技術課長 三 井 經 光

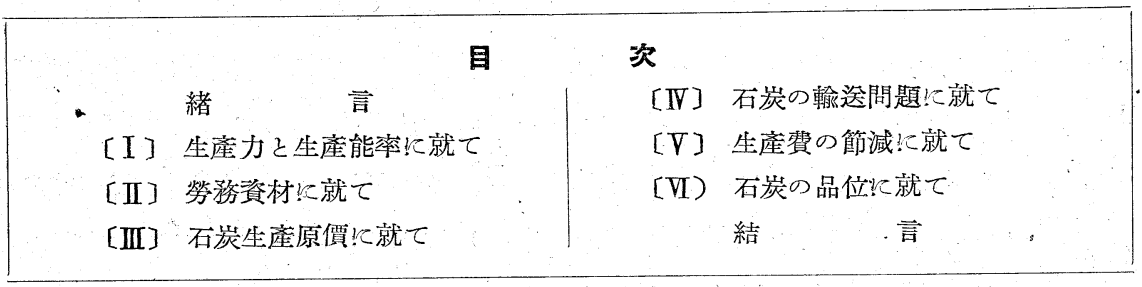

緒言

大東亞戰爭完逐途上の現在，鐵，石炭の問題解決が戰爭の逐行と不可分をる關係にある事は 今更多言を要しない。滿洲事變より支那事變となり巳に 5 箇年を經過し，大東亞戰爭勃發後も 牛歲餘を經過した今日，改善すべを諸問題が生ずる事も亦已むを得ない次第であり，石炭界に 於ても生產力擴充の爲, 解決を急ぐべを 幾多の問題がある。節ち，（1）生産力と生產能率の 問題，（2）勞務資材の問題，（3）石炭生產原價の問題，（4) 生產經費節減の問題，(5) 輸 送の問題，（6）石炭品位の問題等は其の主なるもので,之等㳉又一體不可分の關係をなして益 ふ複雜となつて居るのである。此處に現下當面せる問題二, 三の解說を述へ，諸賢の御叱聲を 煩らはす次第である。

[I] 生產力と生產能率飞就こて

御承知の如く，內地石炭業汢大正の末期上り昭和の初期にかけて非常なる不況に遭遇し，經 營者多技術者も一團となつて之が打開を策して來たのであるが，其の結果探炭方法の改善, 仕. 事場の集約飞努め，之飞件ふ內外の機械化を見事完成して，昭和 8，9 年には其の能率は最高 となり，內地炭田の炭層の賦存狀態は外國に比し不良であるに拘らず，技術者の努力に依つて 之が解決を在し得て，當時豫想せられながつた程の成績を獲得したのである。北海道の或る炭 礦の如きはドイツのそれに匹敵する樣な成績にまで向上して參つたのであるが，然し乍ら，此

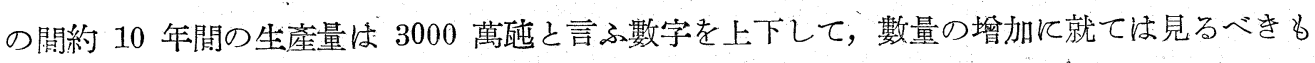
の注どなかつたのである。依つて其後技術者流實せられ，熟練從業員を以て之に當つた事 は當然の事である。滿洲事變が勃發し，支那事變となり，國際閒の緊張が續き，從つて我が國 の必要とする石炭の需要激增を充えすえめ增產の緊迫を來たし，之に應ずるため荅炭礦業者は 一應能率を犧牲にして極度の增產を圖り，各所に新坑開發が行沈れ，中，小炭礦が簇生しれの “である。此の結果，數量は直線的に增大を示し飛躍的增產をなす事をな得だの゙あるが，種ふ 
の理由から能率は逆飞低下の一路を辿り，舊坑は次第に深く廣く成り，勞力，資材を多量飞必 要とするに至り，それと同時に新開發の炭礦はな注莫大な資金と資材，勞力を投ぜざれば全能 カを發揮せしむるに至らず，中に注起業の亂立の営，一應の整理は已むを得ない實情を生じて 居えものもあつれ樣である。斯くて昨年 12 月 8 日，大東亞戰爭の勃發により，石炭の需要 は益く其の多きを加へると同時に，特殊產業に對する優良炭の需要が急激な增加を見るに至つ そのである。斯くの如く，石炭生産業者が國家的石炭の需要に對し，能率，利潤老一應犧牲に

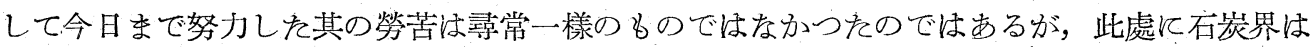
丈ふ一大試練に遭遇するに至つたのである。てれだけの大戰爭をやつて居るからに゙はゆるも

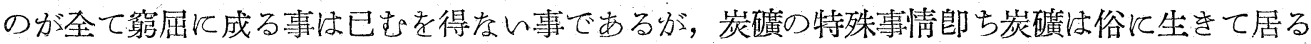
と云はれておるが，動物が每日適量の食糧を得て生存してるると同樣に，或る一定量の勞力と 資材の供給なくては折角開贅しそ坑內の作業場は崩落して死滅に至るもので，一般工場の如く 原料不足の時に一部の中止又は休養を行ひ，原料入手の後操業を容易飞開始するが如を江到底 不可能の事で，一部の休業，一時の中止沈之が廢毫を意味するものであり，勞力，資材の筙屈 が其の操業汇影響するとてろ斯くの如く深刻なものがあるので，一定の資材で最大の能率を舉 げる爲には重點的配給となり，非能率的部類の整理な又已むを得ない次第である。斯くの如き 見地に於て今日目前の生產量に就ては過去の如き直線的增產を期待するには非常なる無理があ る事艻御了解出來るとと〉思ふ。

双て，將來は如何之言ふれ，假りに炭田のありのま〉の姿に其の開發が整理せられ，技蒾的 に飛躍的の向上があるとしても，我が內地の石炭埋藏量は約 150 . 億能で，乙れを佛國炭田の 埋藏量約 200 億酏，年產 5000 萬酏內外の產出を續けてるるに過ぎない狀態より推定すれば 數區域に分散せられて居る我が內地の炭田は佛國の炭田に比し非常に有利とは考へられないの である。

\section{第 1 圖丙地出崖能路圖表}

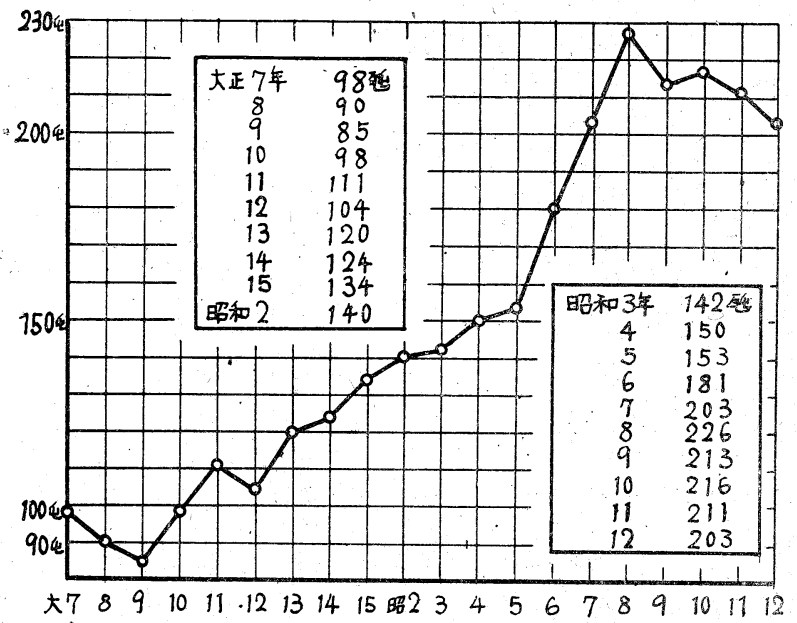

[II] 勞務資材佀 就て 周知の如 $<$, 石炭㹥天然賦存 のもので, 其のありの睢の狀況 に最適最善の施策を行ひ, 最高 の技術を發揮しなければならな 几。炭層飞變動があり，炭質 にも變化があつて，地盤は常に 移動を續けて居り，從つて之を 探掘する仕事場注深く廣く常江 移動して一時も止る所がない。

此の變化江即應する適確なる解決てそ炭礦經營の善惡を左右するものである。空氣銃の的摮ち 
は百發百中の者も相手の動く雀は之を擊ち取るには更に數倍の訓練を必要とするは誰しも異存 ‘はないと思ふ。相手の移動する炭礦は之に從事する從業員が一般の他產業より更に優秀なる技 能者を必要とするに關らず，原料產業なるが故に苦力でも牛島人でも就業せしめてたら゙頭數の みを揃へて此の仕事が出來ると考へられ居るが如きは誤解も甚だしい次第である。

物の管屈は技倆と精神力で補つててそ其の目的を達し得るのであるが，最近の勞務員の質の 低下は技倆の外飞忍耐，勤勉と云ふ精神力にも著しい差異を生じて居るのである。「健全なる 精神は健全なる身體飞宿る」どはての間の事情を物語つてるるものと思ふ。統計の示す所に低 れば炭礦の仕事は新參の者でも亦山新參の者でも馴れる迄には相當の日數を要し，此の間に負 傷をするものが多んのであつて，兔色角山に古いと云ふ事は何處かに取㨅があつて，今日の如 く炭磺勞務員の就業年數が平均 8 箇月內外と云。移動を以てしては訓練も技能向上も出來を ものではないのである。或る石炭の權威者がそれで產業戰士とは情ないと言はれそが，誠てそ の通りである。今日勞務者諸兄の一層の自誐を祈ると共に移動防止に就て萬全の對策を必要 とする次第である。今日 1 人の勞務者募集に直接費 100 圆內外を要して居るが，假りに全國 に於て 1 箇年閒 40 萬人の勞務者募集が必要とすれば, 1 䇢年に 4000 萬圓の經費を要し, 此の募集を 1 箇年止める事が出來れば，4000 萬圓，2 箇年で 8000 萬圓の炭礦の經費が少く なり，勞務者の慰安，福利施設に相當なる設備が出來，災害は少くなり，能率は向上して直接 利する所極めて大なるものがある。勞務者充足の必要は刎論の事乍ら，今日ての移動防止の解 決により，炭礦の問題の大部分が解決出來ると云つても過言ではないと考へるのである。急速 て劃期的對策の樹立を切望して止まない。

\section{[III] 石炭生產原價飞就 て}

石炭生產の經費が石炭の天然賦存の條件飞依つて直接左右せられる事は周知の如くである。 他の生產工業に於ては同一製品の生產工場の生產原價は其の開きが僅少に止るのであるが，炭 礦では石炭の賦存の條件によつて 2 倍，甚しきは 3 倍にもなる例は珍しくないのである。

炭礦は生產力と生產能率の項に於て述へた通り, 直接的又は間接的に政府の生產指導に服 し，戰時需要を機械的に各炭山に割り當て一定割合の增產を强行した結果，「山が荒れ」て來 そ時飞, 勞力資材垟飞生活必需品の窮屈, 物價の昂騰, 技能者の不足, 石炭賦存の天然條件の 惡化等により能率は次第に低下をなし，原價の昂騰は上景の一路を迎つたのである。

政府は昭和 16 年度の石炭買取り補償金飞對し 17 年度は相當量の增額をなし，優良炭に重 點をおき交付せられる事になつたのではあるが，生產原價の上昇飞對し補償金の增額が吊合つ て居ないのでは無いかと思はれる。從つて政府に對し補償金の增加を要求する一方，業者は勞 働力，資材の節約，勞務者の訓練，技術的合理化飞依る機械化，勞働時間の改善等を早急飞圖

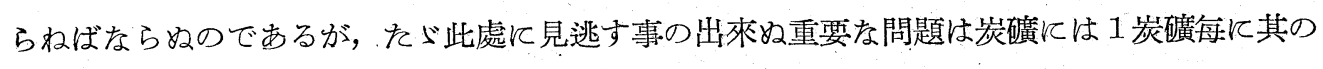
區域の炭量, 其他天然の自然的要素に依る最適經營規模と稱すべきものがあるのであつて，增 産はての自然的，經濟的諸條件によつて行ふべきものであると考へるのである。之は自由經濟 
第 2 圖 直接生産費 指 数

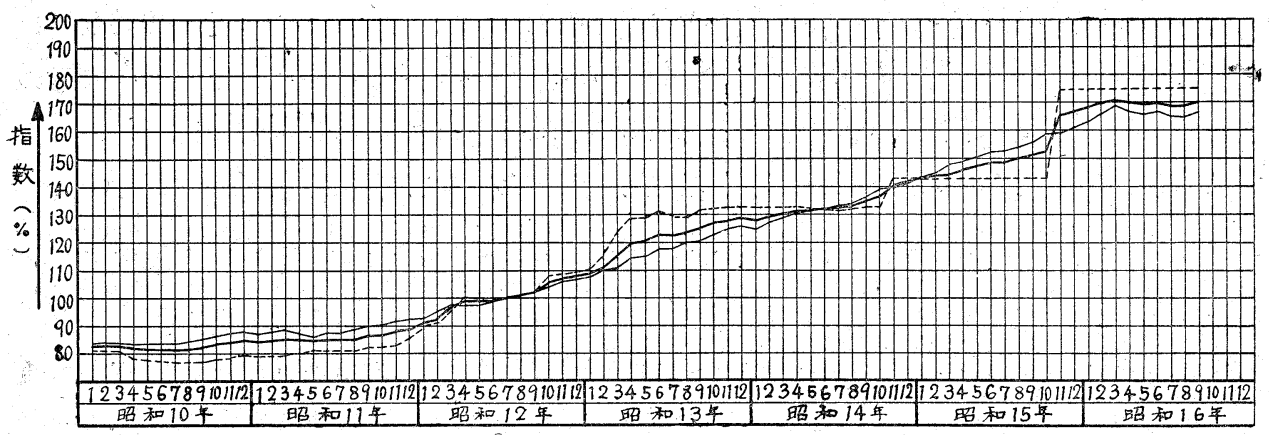

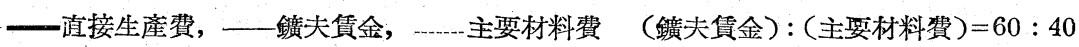

時代の最も有利とした經營方法とは自ら異るものである事は當然の事であるが，機械的，盲目 的なる增產の强行は決して生產力の增强にはならない事を明記しなければならぬと思ふのであ る。斯くて最も有效的な資材及び勞力の使用飞依つて，即ち石炭も最少の費用を以て生產し得 るものと考へるのである。

\section{[IV] 生產費の節減に就て}

てれまでに非能率的炭礦の統制と云ふ言葉が新聞紙上に幾度か載つてなを事を記憶して居 る。そして非能率炭磺は之が統制を必要とするのかとの疑問が一應起るのでするが，日本の炭 田は外國の炭田に比し褶曲が多く，大きく緾つた區域が少いのであり，從つて之應方る適當 な規模の炭礦が生ずる事は當然であつて，小炭礓必就し不可とは限らないのである。然し， 詳細に炭田を調べてみると，所有權を異にした鑛區が大小大り亂れ雜然たる形相をなして居 り，之を基礎にしれ炭礦は自由經濟時代の遺物として，統制を必要とするもののある事は容 易飞想像せられるのである。今日の如く生產能力, 資材の點から重點的配給が行林樣汇成 り，勞力と資材とを國家として最も有效に使用する䈆とは無駄をなくする秛，非能率的炭礦が 話題になる事はてれ亦當然の次第である。

統計の示すとてろに依れぱ，規模別能率（福岡管內）は次の通りである。(昭和 16 年度）

\begin{tabular}{|c|c|c|c|c|c|c|c|c|c|c|c|c|c|c|c|}
\hline 規 & & & & 模 & 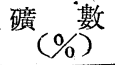 & $\begin{array}{c}\text { 勞務者數 } \\
(\%)\end{array}$ & 能 來 & 㚘 & & & & 模 & 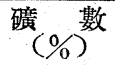 & $\begin{array}{c}\text { 勞務者數 } \\
(\%)\end{array}$ & 能 率 \\
\hline 30 & 萬 & 酎 & 以 & 上 & 7 & 51 & 100 & 5 & 萬 & 酎 & 以 & 上 & 7 & 8 & 60 \\
\hline 15 & 萬 & 䣶 & 以 & 上 & 6 & 17 & 70 & 5 & & 酎 & 以 & 下 & 74 & 12 & 49 \\
\hline 10 & 萬 & 䠛 & 以 & 上 & 6 & 12 & 64 & & & & & & 100 & 100 & \\
\hline
\end{tabular}

郎ち福岡管內に於て昭和 16 年度は 5 萬䣩以下のものの能率が 30 萬醞以上の炭礦の平均能 率の牛分と云ふととになる。又, 昭和 16 年度に於ける全國規模别礦數の割合(\%)を示すと次 の如くである。 


\begin{tabular}{|c|c|c|c|c|}
\hline 30. 萬然以上 & 15. 莴酉迍以上 & 10 萬䣩以上 & 5 萬䣩以上 & 5 萬䣩以下 \\
\hline 4.0 & 3.0 & 4.0 & 3.0 & 86.0 \\
\hline
\end{tabular}

上远の如く，全國炭礦數の 8 割以上が 5 萬酏以下の炭礦である。最も規模の大なる炭礦に は數坑あるのが普通であるから，5萬酎以下の炭礦を規模の大なる山の 1 坑數とみれば，相 當ての割合壮變化して來るが，何れにしても資本の異つれ炭礦が一つの炭田に大小交錯してる る模樣が明瞭に看取され得る。尤子此の小規模の炭礦中には大規模の炭礦汒比し決して能率の 劣らないものも亦り, 又, 內地炭田の規模よりして小規模の炭磺に依る以外に核到底採掘出來 ないものbあつて，要はその天然の條件に最適したる開發てそ望ましい次第である。之に依 つて閵接の人員を減少し, 勞力, 資材を極力節約し, 炏第に地下深く炭曆條件も惡く成つて來 る探掘上の天然條件は機械化によつて之を克服し，多量生產に依る經費の節減てそ國家として 今日程强く要求せられる事はないのである。現在最も重大な問題となうてるる勞力資源に就て も炭礦勞働者の本均 1 日賃金は統計によれば 3 圓 70 錢, 工場の勞働者の賃金は 3 圓 50 錢 見當で，月收得になると炭礦汇遙に少く，昔注炭礦勞努者の收得本均が最高であつたのが，最 近は他產業勞務者の平均收得に比べて産業別の略了中位に位してるる狀況である。てれでは暗 黑の地下勞働には就業者が少くなるのは當然であつて, 佳宅にしても, 慰安訓練にしても, 何 一つ他の重要產業部面のそれに勝るタのはないのであつて, 內地人勞働者の炎礦就業飞對して は劃期的の大改革なくしては增加の見达はないのである。其の結果は必然的に牛島人とか苦力 とか云ふ事になるであらう。数年前英國に滯在中, 英國の地下勞働者は本來の英國人ではない と云ふ事を聞いたが，然ましい事ではないが，今にして考へると結局日本內地も英國と同樣の 狀態が近き將來に來るのではなからうか。斯樣になるものと假定しても，治安の問題から小規 模の炭礦は內地人同樣に自由に之等の者を雇傭出來るとは當分考へられないのである。

統制と云へば直ちにドイツの話が出るが，ドイツの炭磺海第一次世界大戰敗戰後の產業界の 大打擊により自然陶汰が行はれ，其の後產業包復のため憤重なる對策研究の結果，少數大會社 の金下全國の炭礦を統合して重點的開發を行ひ，機械化を强化して生產力と能率は飛躍的に 增加したのであつた。今次大戰前, 節ち 1913 年から約 30 年の閒に於て如何なる增加率を示 したかを見るに，戰勝國の英國，佛國は礦夫 1 人當り出產量は殆ど增加なく，ドイッは舊に 倍する增加を見せて戰前礦夫 1 人當り 1 日出炭量 0.95 䣩が 1.63 襾になつて居り，1 炭礦 當りの 1 年間本均出炭量8英國等飞比し 2 倍以上の生產をなしておるのである。此のドイッ の躍進は同國石炭礦業の中心をなすルーア炭田の全體主義的見地に立脚した集約化の賜物に外 ならぬのであつて，不況と苦難との試練に耐えて僚む事なく工夫と努力を續けを結果であり， 以て模範とすべをbのではなからうか。

\section{[V]．石炭の輸葖問題に就て}

石炭輸送の問題が種々論議の的となつて來たが, 輸送飞關しては國家の物動に關する事で記 述の自由を持たす， 文その詳細は知る由もないのではあるが, 石炭の生產地と非常な遠隔の 
土地に大工業が設立せられて居る日本にあつては，此の問題の極めて重要なる事は當然であつ て，恐らく石炭の生產地と消費地の離れてるる事は世界第一と思沈れる。輕工業上り重工業人 と漸次移動して來れ日本に於ては巳むを得ない事で沈あつたてとと思はれるが，工業立地計畫 として，將來多くの石炭を消費する工業に就ては，石炭生產地と輸送の問題を從來考へられた 以上に考虑せられる必要を痛感するものである。

劣，6月 1 日上り 7 月末日迄 2 籄月間石炭統制會注企畫院，商工省の後援捠つて選炭 强化期閒を實施して居るが，要法選炭作業に從事してるる者て對し我が國が目下如何なる石炭 を必要して居るかを熟知させると同時に，出來るどけ消費者に優良炭を供給し，輸㑒の困難を 克復して䢝つた石炭が少しでも多く國の爲になり得る樣に努力せしむると云ふ事であると考へ る。又，石炭は周知の如く，植物が地中に埋没して押し付けられ乍ら地曆の變動や地熱，火山岩

第 3 圖 混合原岸の可洗曲線

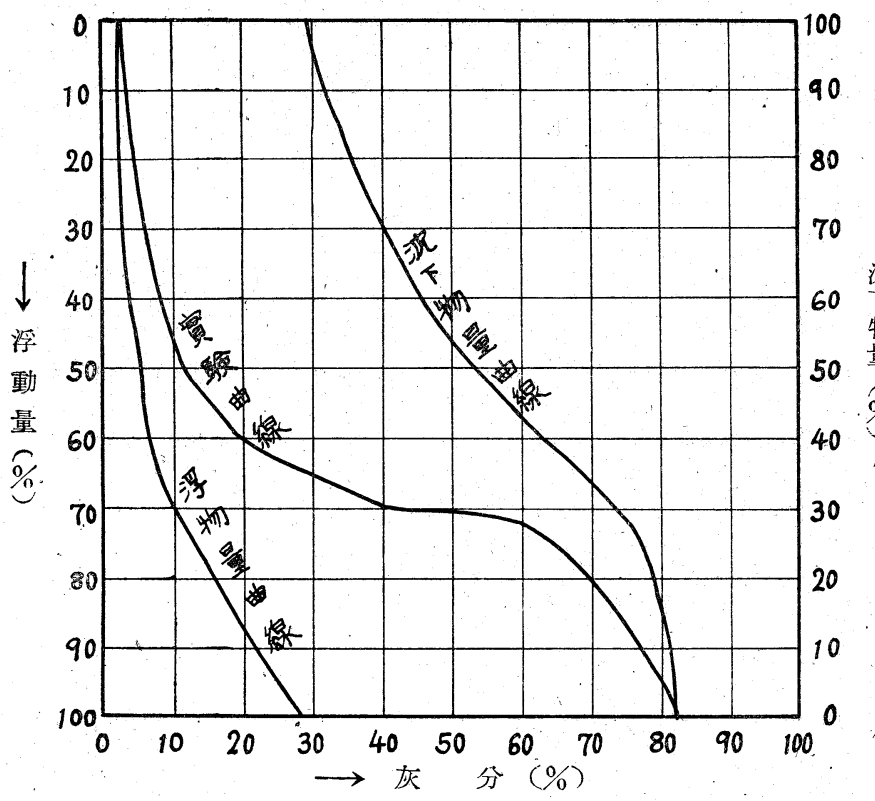

第 4 圖：精炭の灰分を變化せしむる場合に於ける精岸，二號岸， 廢石の量及び灰分の變化を示す例圖（可洗性曲線より 求めたるもの)

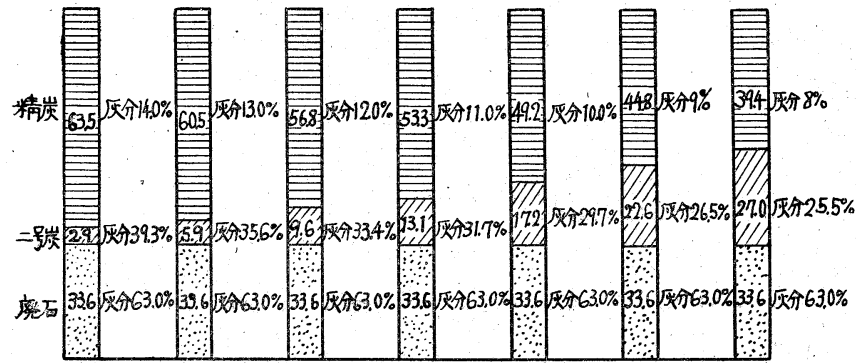

等伴雀依つて天然に 乾餾せられた可燃性の固體 であうて，概ね陸生植物特 に樹木から生じたものと云 はれて居るが，樹木はその 組織上空隙に粘土質又は砂 や石灰分等が侵大し，樹木 の灰分汒之等のものが加つ た石炭の持ち前の灰分之， 石炭生成の際江覆ひかぶさ つを粘土文は砂が層をなし て石炭の中に大つておる俗 飞狹みと稱せられてるるも のとがある。この狹みは石 炭探掘の際石炭に附着丈 は混大し, 之を取り除くに 汢大塊注手で選り，小塊や 粉炭江水又は空氣を利用し て然へ易いもの之燃へ難い タのと比重の差で洗別して るる。水洗の際汁何れの原 炭でも第 3 圖に示す樣な可 洗曲線が作られるのであつ て，之依る之灰分5\%以 下の精炭は $25 \%$ しか包收 
出來ず，灰分 $20 \%$ 以下のbのは $60 \%$ 包收が出來るのであつて, 此の可洗曲線から第 4 圖 の樣な精炭の灰分を變化させる場合に於ける精炭，二號炭，廢石の量及び灰分の變化が分るの である。之依つて明らかなる如く，精炭の灰分を少くして優良炭の品位を向上すると，燃一 難い二號炭が吹第に增加し，之によつて洗炭飞經費がかかると同時に優秀炭の量が少くなり， 二號炭の處分に生產者注困る樣なととになるのである。從つて今日, 生産者には益々選炭の强

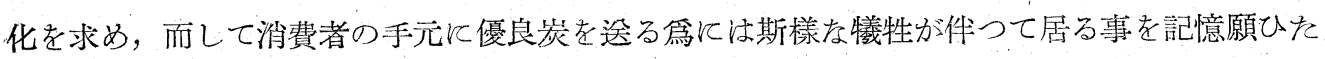
いのである。又，二號炭でも當然閒飞合ふ工業もある事之思ふから，之等の利用方法考考慮し て頂く事と，遠距離の輸送を要しない樣になるべく生産地に近い所に於て利用される樣に願し れんものである。

\section{[VI] 石炭の品位飞就て}

石炭の消費之生產は當然バランスしなけれはならないのであるが，年ふ消費量汁可速度的に 累增しており, 特江最近洔特殊產業飞對する優良炭の需要が著しい。日本內地江一般に低品位 の瀝靑炭に就て江其の埋藏量は相當にあるが，高度瀝青炭端に原料炭は其の量が非常に少的の である。從つて今日生產業者は此の困難に打ち勝ち, 多量の優良炭を消費者に供給しなければ ならない。然るに, 輸送の點より九州及び本土の炭礦に當分重點を置かなければならぬ現狀に 於ては益及之の供給を困難ならしめて居るのである。九州及び本土の炭田注青年期を已に過ざ

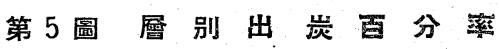
(昭和 $9 \sim 16$ 年)

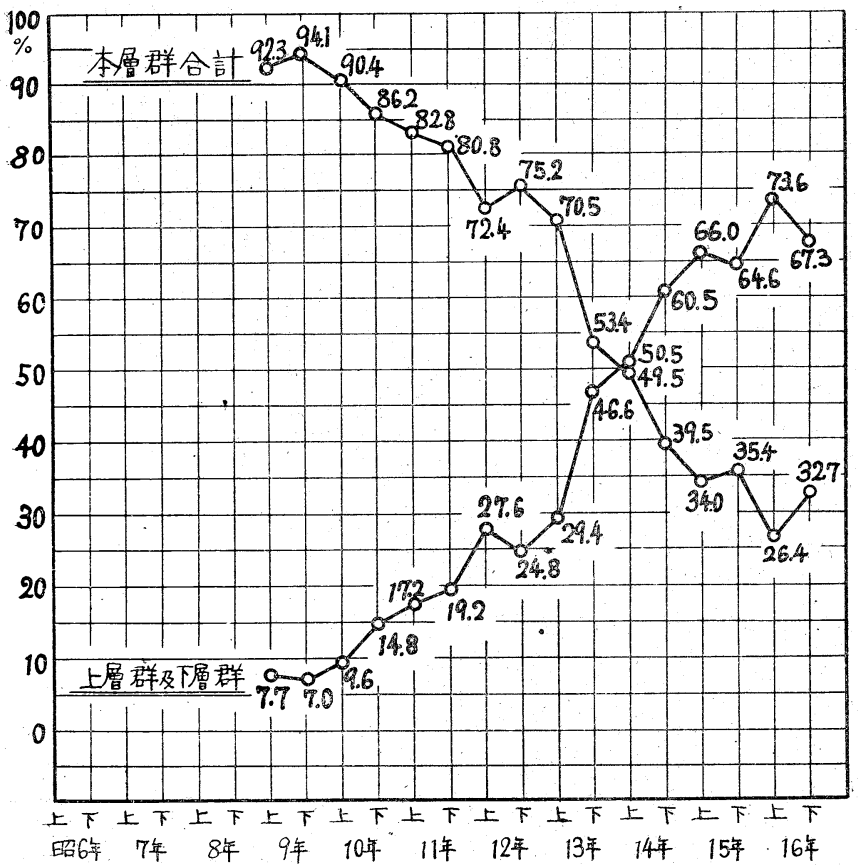

そ炭田であつて，最盛期を 過ぎた炭礦が多數ある事も 亦已むを得ないのである。 炭礦の經營江當つて, 最

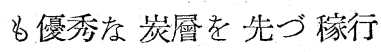
し，技術の進步に件ひ從來 經濟的江稼行の價值の类 つをものが次第飞價值を生 じて來るのが普通である。 第 5 圖注其の實例であうて 九州の或る地域に於ける優 良炭層群 (本層群) と低品位 炭尿群 (上㕌群及び下愿群), 此の中に沈以前飞嫁行出 來ぬ之考へられてねを当の 当つたが，之等の炭層化 於ける1年間の生產江數量 的には大體同じ生產量を維 
持しながら，昭和 14 年の初めに完全に入れ替つた事が明らかにされて居る。㴧ち數量的に は假りに生産量が同じであつてもその內容は斯くの如く變化しつ〉あつて，次第に低品位炭 が增加しつ」ある事が想像出來るととと思ふ。前述の輸迼問題の項で述べた如く，之等の低品 位炭から灰分の少い優秀炭を引き拔く之二號炭と稱する然え難い炭がいが多く山元に停溲し

第 6 圖 在䧼 1 人 1 箇月出哭顿數（昭和 10１6 年）

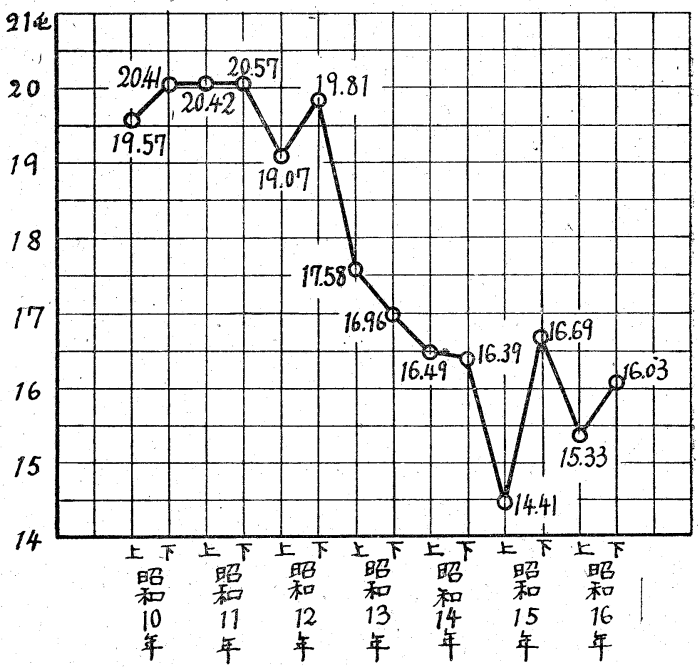

第 7 圖 昭和 10年上期の䣩當經費及び 1 工當㑤 金を 100 之世る各斯别指數表

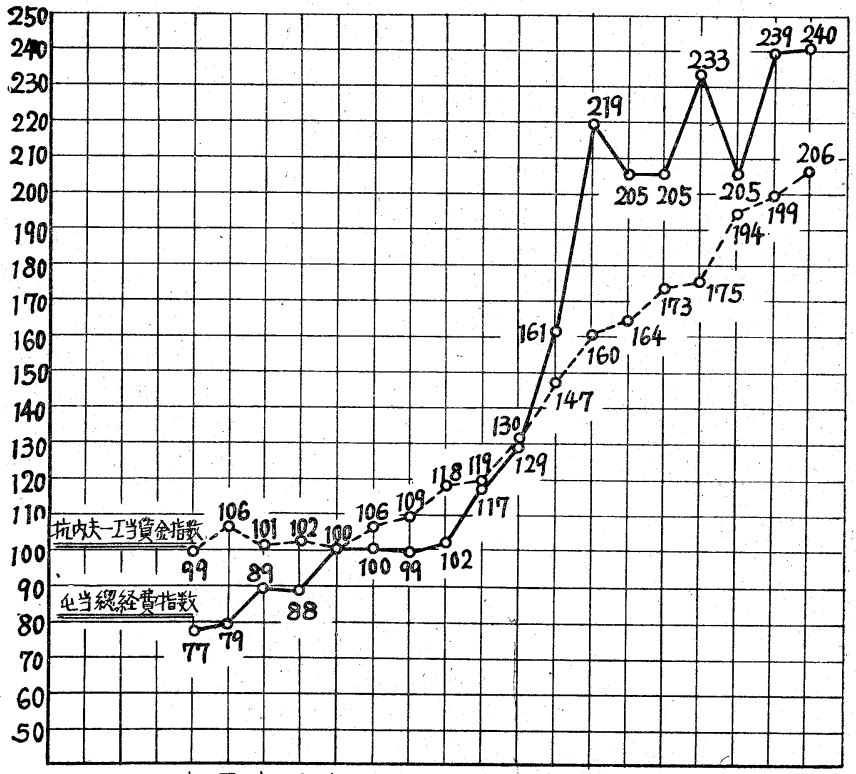

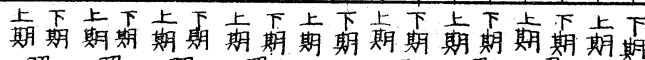

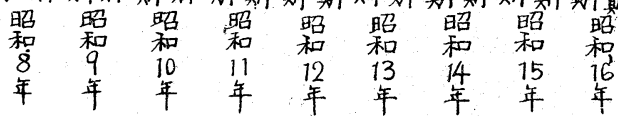

て來る樣になるかと云ふ事 8分るととと思ふ。。 餘談な がら生產者が之に依つて如 何なる苦勞をして居るかを 述ぶれば，第 6 圖の如く年 卒能率流低下を來えし，昭 和 10 年頃 1 人當 b本均 20 酎以上( 1 箇月) の出炭 をなしてみたものが昭和15 年には 14.5 酎に減じ, 其の 生產費の指數江第 7 圖に示 す如く昭和 10 年を 100 と すれば，昭和 15 年には233 と云ふ2 2 倍牛に近い數字を 示して居る。之は一般生產 原價の上昇に加へて，炭層 の探掘上の不利に件ふ能率 低下とか, 資材使用量の增 加とか，選炭經費の加算等 が其の主なる原因である。 斯かる狀態が炭礦今日の一 般の趨勢である。要するに 低品位炭の數量的增加が生 和万事は必然の事であつ て，之が利用を御願ひする 之共に, 現在使用されて居 られる石炭が斯くも勞苦し て生產されて居る事檍ひ を致され，之が合理的使用 方法の研究を進められん事 を切得希望して止ま奴次第 
である。

\section{結 $\quad \overrightarrow{\overline{1}}$}

以上纏りのつか私見を以て難しい石炭問題二三に就て解說を試みたが，てれ丈の問題でも 之を解決するには尋常一樣な事ではないのであつて，それにつけてる或る政府の高官が，「啼 かざれば啼かしてみせよう杜鵑」又は「啼かざれば啼くまで待たう杜鵑」等では駄目だ。現在 の時期は「啼かざれば殺してしまへ杜鵑」の意氣だと，本年 1 月 3 日增産期間全國優良勞務 者表彰祝賀會で和話しになつたが，事實此の問題はこうした實行力に依つててそ解決が出來る ものと思ふ。お互に國家のため益々斯界改善に遇進すべきもと考へる。最後に述べたい事は 全般の石炭問題注內地だけでは到底解決出來ない事であつて，前述の如く，內地の石炭生產に は限度があり，每年急激江累增して居る石炭需要の增加は大東亞共策圈の石炭の。開發之之が依 存に待つ外はないのである。內地の經驗と技術を以て共榮圈の石炭の開發と之に關聯せる工業 立地の計畫てそ緊急なるものと考へられるのであつて, 至急政府に於て强力なる對策機關の設 立を要望する次第である。

\section{訂 正}

本誌第 237 號所載のブタノール, アセトン蒸溜裝置に於て, 587 頁 13 行以下 20 行目まで次の如く訂正する旨著者より 申出でありたるにつき訂正す。

第一型式の如き基本型式に於ては大體次の如くである。

醪 1000 石當り蒸氣消費量（土10\%）27.0t

醪 $1 \mathrm{t}$ 當り " ( ") $0.15 \mathrm{t}$

ソルベント" $"$ (" $) 6.9 \mathrm{t}$

ブタフール" " ( " ) $10.7 \mathrm{t}$

又第二型式の如き基本型式に於ては次の如くである。

醪 1000 石當り蒸氣消費量（士10\%）23.6 t

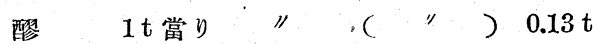

ソルペント" " $"(") 6.1 \mathrm{t}$

ブタノール" " ( " ) $9.2 \mathrm{t}$

(編 輯) 